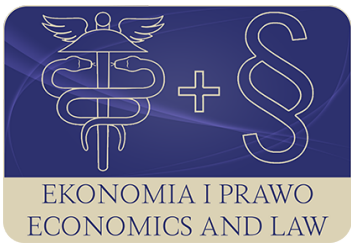

EKONOMIA I PRAWO. ECONOMICS AND LAW

Volume 20, Issue 4, December 2021

p-ISSN 1898-2255, e-ISSN 2392-1625

www.economicsandlaw.pl

ORIGINAL ARTICLE

received 30.04.2021; revised 01.12.2021; accepted 31.12.2021

Citation: Walkowiak, K. (2021). Institutional conditions for the implementation of sustainable development on the example of self-governing agricultural bodies in Poland. Ekonomia i Prawo. Economics and Law, 20(4), 887-901. https://doi.org/10.12775/EiP.2021.053.

\title{
Institutional conditions for the implementation of sustainable development on the example of self- governing agricultural bodies in Poland
}

\author{
KATARZYNA WALKOWIAK \\ Adam Mickiewicz University in Poznań, Faculty of Political Science and Journalism, \\ ul. Uniwersytetu Poznańskiego 5, 61-614 Poznań, Poland \\ ■ katarzyna.walkowiak@amu.edu.pl \\ (D) orcid.org/0000-0002-1568-7277
}

\begin{abstract}
Motivation: The need for balance in the social, environmental and economic developments has been explored by numerous academic disciplines and fostered the implementation of subsequent political agendas both at the global and local levels. The 2030 Agenda for Sustainable Development adopted by the United Nations in 2015 is an example of an

international initiative for sustainable development. All the goals of the Agenda were determined in view of global civilizational challenges, but in order for them to be implemented various stakeholders have to be involved, and projects on a national, regional, and local scale have to be carried out. Given the postulate of creating multilateral public and public-private partnerships for sustainable development and the principle of subsidiarity, it seems important to take into account the role of self-governing agricultural bodies in the system, implementing sustainable development goals. Agricultural self-governance is exercised in Poland through agricultural chambers established as public-law associations, forming part of the institutional system of public administration. The scope of tasks performed by these agricultural chambers covers matters of agriculture and rural development, including sustainable development.

Aim: In her study the author seeks to answer the questions of whether the self-governing agricultural bodies in Poland are the key entities in the implementation of the postulates of sustainable development, or whether the competences of these agricultural chambers
\end{abstract}


allow them to fully use the social potential of farmers for the dissemination of the concept of sustainable development.

Results: The results of the survey demonstrate that the self-governing agricultural bodies play only a superficial role in the implementation of the sustainable development postulates. Although these agricultural chambers are formally established in the public law system, they do not have sufficient executive power, or material, human and financial resources to engage in effective action. The potential of the self-governing agricultural

bodies to achieve the goals of sustainable development is not being fully used.

Keywords: sustainable development; sustainable development goals; self-governing agricultural bodies; tasks and competences of agricultural chambers

JEL: K19; P32; Q56; Q58; Z18

\section{Introduction}

The challenges of modern civilization (poverty, hunger, environmental pollution, climate change, limited natural resources, overproduction and excessive consumption, unequal access to public services, human rights violations, and so on) have raised public awareness of the importance of sustainable development. That is why this concept continues to be addressed by the academic community, central and local government institutions, business, non-governmental organizations, and many other entities responsible for development processes.

The main goal of sustainable development is to achieve a balance in the areas of economy, society and nature. The specific sustainable development goals adopted by the UN in 2015 are about providing humanity with high-quality health care and education, decent work, gender equality, the rule of law, civic participation, peacekeeping and respect for human rights. In the field of economy, the need to balance production and consumption is stressed and natural environment requires rational planning and space management, land use, and the protection of biodiversity (United Nations, 2015).

In order to maintain the coherence of the various dimensions of sustainable development, the concept of Policy Coherence for Sustainable Development is promoted. One of its aims is to promote partnership and cooperation; involvement of regional and local authorities to align priorities and promote coordinated actions to support the implementation of the 2030 Agenda, among other things (OECD, 2019). This concept is therefore embodied by dialogue and commitment, thanks to which central government, local governments and other key stakeholders are able to jointly identify problems and challenges, set priorities, develop action plans and organize resources for sustainable development. Active involvement of stakeholders at all stages of creating public policies, exchange of knowledge, and conflict resolution are all methods that foster maintaining the symmetry of interests of various social groups and raise social awareness, as a result of which sustainable development goals can be implemented.

Sustainable agriculture and the sustainable development of rural areas represent a particular challenge. Systems of sustainable food production and adapta- 
tions of agriculture to climate change need to be developed. Investments in rural infrastructure, access to up-to-date information and expertise remain of crucial importance. The institutional system is one of the most important determiners of the implementation of the sustainable development of agriculture and rural areas. This system is made up of formal and informal instruments, and so all organized forms of activity, specific principles of their operation, organization and management methods, applicable legal regulations, as well as knowledge, behavior and social attitudes.

Goal 16 of the 2030 Agenda is to "(p)romote peaceful and inclusive societies for sustainable development, provide access to justice for all and build effective, accountable and inclusive institutions at all levels"; one of the tasks related to it is to "(e)nsure responsive, inclusive, participatory and representative decision-making at all levels" (United Nations, 2015, p. 25). In the implementation of the basic goals and tenets of sustainable development, a special role is undoubtedly assigned to farmers and entities related to agriculture and rural areas. Given the postulate of creating multilateral public and public-private partnerships for sustainable development and the principle of subsidiarity, it seems justified to address the independent role of self-governing agricultural organizations in the system for implementing sustainable development goals. Self-governance in agriculture in Poland is exercised through agricultural chambers, established as public-law corporations forming part of the institutional system of public administration. Among the many tasks of the chambers, promoting the development of agricultural and rural infrastructure, forming environmental awareness, as well as information, advisory and promotional activities should be stressed. The role of agricultural self-governance in shaping the social environment of farmers is also important (Zieliński, 2012, pp. 309-314).

The literature on the subject emphasizes that stakeholders' self-governance and participation are a means to increase the understanding and effectiveness of actions; they help to achieve social cohesion; increase transparency and accountability; strengthen the sense of empowerment and people's ability to learn and act (Arnstein,1969, pp. 24-34; Bernaciak et al., 2018, p. 120; Pawlewicz \& Pawlewicz, 2010, pp. 71-80). It is impossible to achieve sustainable development without social participation, cooperation of various institutions and organizations, combining various fields of knowledge, and referring to informal instruments. In Poland, however, public involvement in various public initiatives is limited (CBOS, 2018, pp. 4-11; Zielińska \& Kraszewski, 2019, pp. 3-21). Research confirms that local communities, among others, do not have a sense of empowerment or of real influence on the decision-making process, even though these are formally provided (CBOS, 2018, pp. 4-11; Szostok-Nowacka, 2019, pp. 142-155).

Agricultural self-governance has been exercised in Poland for over 25 years. This temporal perspective makes it possible to analyse current legal solutions and the practice of agricultural chambers and draw productive conclusions re- 
garding the development of self-governance and its role in the implementation of sustainable development.

\section{Literature review}

As early as the end of the 18th century and the beginning of the 19th century, scholars began observing the problems of growing populations, diminishing natural resources and the related threats (Mensah, 2019, pp. 6-7). J.B. Say was "the first among the representatives of classical economics to notice the problem of environmental pollution as a consequence of production and consumption processes" (Kołodziejczyk, 2013, p. 55). Although problems had been identified earlier, the concept of sustainable development is believed to have been internationally addressed for the first time at the Stockholm UN Conference on the Human Environment in 1972. In 1987, the UN's World Commission on Environment and Development (WCED, 1987) published a report entitled Our common future (also known as the Brundtland Report). In the report, sustainable development was defined as that which satisfies the needs of the present generation without compromising the needs of future generations (Pawłowski, 2017, pp. 57-62). This report contributed to the UN's Conference on Environment and Development (UNCED), known as the Rio Earth Summit, organized in 1992. Agenda 21, published after the Earth Summit, recommended that national strategies take into account the economic, social and environmental aspects of sustainable development (United Nations, 1992).

Another global plan for achieving sustainable development is the 2030 Agenda adopted at the New York UN summit in 2015 (United Nations, 2015). The 17 Sustainable Development Goals identified in the 2030 Agenda are intended to contribute to eradicating poverty and hunger, ensuring universal access to basic services such as water and sustainable energy, creating opportunities for development through education and decent work, supporting the innovation and infrastructure that enhance sustainable production and consumption, reducing global inequalities, protecting oceans and terrestrial ecosystems, and promoting cooperation between different social actors (Saner et al., 2019).

Achieving the goals of sustainable development depends on many factors. One of the most important factors in the sustainable development of rural areas is the institutional system. The core of the institutional system lies in collective and organized action to shape, direct and stimulate the behavior of individuals, in order to for them to develop (Godłów-Legiędź, 2009, p. 16; Hodgson, 2004, p. 424; North, 1990, pp. 3, 204; Ostrom, 1990, p. 51; Rudolf, 2015, p. 116).

The implementation of the 2030 Agenda and the Sustainable Development Goals therefore requires appropriate institutional solutions in public and private sector organizations to include balanced out economic, social and environmental priorities in the decision-making processes and implementation of public policies. These organizations also need the strategic vision, capacity and tools 
to anticipate future trends and relationships, and understand the changes they may bring in the economic, social and environmental areas in order to properly design solutions for the future. The European Commission (2015, pp. 7, 14) has identified the effective institutions, as well as the human skills and capabilities necessary to eradicate poverty and ensure sustainable development. Popławski (2000, p. 189) also believes that the general public is largely responsible for the implementation of the sustainable development postulates. This entails that public knowledge and skills in the field of environmental, economic and social care need to be developed (Collste et al., 2017, pp. 921-931). Sustainable development goals are mutually closely related. On the one hand, they are complementary, but on the other, they can also trigger contradictions and the need to seek compromise (Tosun \& Leininger, 2017). These issues are of even greater importance, and deserve more attention as concerns agriculture and rural areas, since activities related to agriculture and rural areas are closely related to nature (Adamowicz, \& Zwolińska-Ligaj, 2009, p. 21). At the same time, this close relationship between agriculture and nature is often a source of conflicts of interests (social interest and the interests of agricultural producers) that may threaten sustainable development. It is therefore argued that the process of sustainable development has to be participatory in order to be effective and lasting (Pretty, 1995, pp. 8-18). The implementation of the postulates of sustainable development is not possible by means of individual, uncoordinated actions. On the contrary, it requires collective responsibility and the participation of all key actors. In this context, operating practices based on the principles of participation, transparency and accountability are required, which strengthen democracy and inclusive development (as indicated by Goal 16 of the 2030 Agenda). Studies confirm that cooperation with a wide range of stakeholders makes public administration and institutions more representative, sustainable and effective in managing public policies (Chatwin et al., 2019, p. 6; Przybylska \& Giza, 2014, pp. 100-105).

In Poland, agricultural chambers play a crucial role in the field of sustainable agriculture and rural development. They are the only public-law corporations among the economic self-governing institutions in Poland (Bandarzewski, 2014; Kmieciak, 2018, pp. 168-177; Walkowiak, 2004, pp. 47-57). Pursuant to the Act on Agricultural Chambers of 1995, they are organizational units of agricultural self-governance, they work in favor of agriculture, have a say in shaping agricultural policy and participate in its implementation. Agricultural chambers differ from other business associations by membership in them being obligatory. In line with the state theory of self-governance, the Act on Agricultural Chambers assumes obligatory membership. Thus, membership of a self-governing entity is established by law, regardless of the intention of the entities that meet the criteria specified in the Act. Like local government units, agricultural chambers, as self-governing institutions which associate agricultural producers by virtue of their obligatory membership, are authorized to represent the interests of the entities covered by their jurisdiction (Wykrętowicz, 2012, 
pp. 79-81). It should be added that the establishment of self-governing entities is closely related to the concept of the decentralization of the state and is connected with the idea of empowering the farming community by enabling them to make decisions on matters that concern them, express opinions on the directions of agricultural policy, and on the development of agriculture and rural areas. The extent to which the self-governing agricultural entities have an impact on agriculture is determined by their system, tasks, competences and commitment of their members (Walkowiak, 2012, pp. 295-306).

As mentioned above, the extent to which the postulates of sustainable development are implemented is influenced by formal and informal instruments. Formal instruments related to self-governing agricultural entities include legal acts regulating the status and scope of tasks and the administrative power of self-governing entities, as well as resolutions of agricultural chambers and strategic documents related to development planning. Formal instruments also include the statutes of the chambers and organizational regulations of administrative units servicing self-governing bodies. Apart from formal instruments, there are many informal ones that complement the former such as opinions, attitudes, customs, traditions, moral and ethical principles, and opportunistic tendencies (Klimczak, 2001, pp. 30-32). These instruments are particularly important in relation to people in power or senior officials working in organizational structures (Rudolf, 2015, p. 116) (in the case of agricultural chambers, these are structures at the central, regional and county levels). It is the attitudes of these leaders, their opinions, and moral and ethical principles that determine their commitment to the activities of the chamber, the degree to which they identify with the interests of the chamber's members and the public interest. What is important in this context is the social capital represented by farming circles. Social capital is essential from the point of view of sustainable development, "both as a regulator of the impact of the economy on the environment, and as the basis for future development" (Kołodziejczyk, 2013, p. 55). Importantly, the farming community has unique potential which can be used for the sustainable development of rural areas and agriculture, by applying appropriate, effective policies (taking into account the social, economic and environmental aspects) and relevant institutional, formal and informal solutions (Springer et al., 2020, pp. 1-2).

\section{Methods}

Summarizing the state of research on the concept of sustainable development and agricultural self-governance, considerable asymmetry can be identified. There is a wealth of literature on sustainable development, while little attention is paid to the self-governing agricultural bodies and their role in disseminating this concept and implementing the 2030 Agenda.

Therefore, in the study conducted by this author on the formal and informal conditions for the development of self-governing agricultural bodies in Poland, 
an attempt was also made to answer the questions of whether the self-governing agricultural bodies in Poland are essential for the implementation of sustainable development postulates, and whether the competences of agricultural chambers allow them to fully exploit the social potential of farmers to promote the concept of sustainable development. The research goal has been achieved by analyzing legal acts, official documents and literature sources, using the descriptive method, comparative methods and the synthesis of survey results.

Purposive sampling was employed in the survey. The first stage of the study concerned respondents who were experts. The aim was to find out the opinions of people who shape self-governing structures and actively participate in the work of the corporate association concerned. These are the leaders of agricultural chambers in Poland (presidents and vice-presidents of regional chambers, members of the National Council of Agricultural Chambers, delegates of county councils and office directors). These people can be assumed to care most about the development of agricultural chambers. The requests for them to participate in the study and complete the questionnaire were emailed to their official addresses. The package included a covering letter and a link to the questionnaire. At the end of the first quarter of 2021, responses were obtained from 89 respondents.

The questionnaire featured questions asking for the assessment of the current operating possibilities of self-governing bodies and the scope of their competences; the respondents were also asked to order the self-governing bodies' competences in terms of their significance, asked about the methods of financing self-governing bodies, the rules of choosing their authorities; the respondents could also indicate what, in their opinion, needed to be changed in the functioning of these self-governing bodies. The final part of the survey featured questions about the concept of sustainable development.

The selection of the research sample makes it impossible for the research results to be generalized for the entire population of members of agricultural chambers, but does allow the author to interpret them from the point of view of people with extensive experience in self-governance and who are authorized to assess the operation of the self-governing agricultural bodies in Poland to date.

\section{Results}

Sustainable development goals were implemented in Poland through the Strategy for responsible development 2020 (with the perspective to continue until 2030) (Rada Ministrów, 2017). The implementation of the 2030 Agenda at the national level is coordinated by the Ministry of Development, Labor and Technology. The Partnership for the Implementation of the 2030 Agenda in Poland was initiated in June 2017, and subsequently joined by several hundred entities representing various circles. The reports on the partnership implementation show that only a few of its signatories committed themselves to the protection of nat- 
ural resources (life on land and life under water). There was also little interest in actions aimed at reducing poverty and hunger. It should be stressed that most of the entities that joined the partnership for sustainable development represent the business community, including large corporations (Rada Ministrów, 2018). The survey results show that many respondents (43\%) found it difficult to assess whether agricultural chambers are sufficiently involved in the implementation of the 2030 Agenda; 31\% believed that agricultural chambers are not involved in this process to the extent they should be, and $26 \%$ of the responses confirmed sufficient commitment of chambers to the implementation of the 2030 Agenda.

The next question concerned the Strategy for Sustainable Development of Agriculture, Rural Areas and Fisheries 2030 (SDARAF 2030) (Rada Ministrów, 2019). This is the main strategy for implementing Goal 2 of the 2030 Agenda in Poland, including, among other things, eliminating hunger, achieving food security, and promoting sustainable agriculture. Due to its various priorities, SDARAF 2030 also aims to foster the achievement of all other sustainable development goals. Unfortunately, the responses of the leaders of agricultural chambers demonstrate that the self-governing agricultural bodies are not the key entities involved in the implementation of SDARAF 2030 and, indirectly, of the 2030 Agenda. According to the respondents (99\%), the self-governing agricultural bodies should ensure greater impact on the development, implementation and monitoring of SDARAF 2030.

Responding to the next question, the respondents stated that self-governing bodies have the potential to shape the attitudes of farmers and inhabitants of rural areas in favor of sustainable development (72\%) and to support farms in the process of implementing the concept of sustainable development (61\%). The leaders declared that the chambers largely take into account the postulates of sustainable development in their strategies and plans. The respondents learn about sustainable development mainly from the self-governing agricultural bodies (due to their positions in the structures of the chambers), as well as from the media, agricultural advisory centers and the Agency for Restructuring and Modernization of Agriculture. The agricultural chambers' involvement in the process of disseminating the concept of sustainable development and its implementation is crucial because, according to the respondents (71\%), farmers have little knowledge about the postulates of sustainable development. At this point, it is worth adding that, despite the chambers' potential in identifying needs, sharing professional knowledge, experience and disseminating the concept of sustainable development, they are not a key entity in the agricultural advisory system or vocational education in Poland. The amendment of legal regulations in 2016 meant that regional agricultural advisory centers, being self-governing regional legal entities, became both regional agricultural advisory centers and state organizational units. The basic premise for changing the subordination of the centers was to improve the competitiveness and development of agriculture and rural areas by improving the implementation of tasks related to providing agricultural advice to farmers. Yet the respondents (78\%) 
indicated that agricultural advisory services should be organized primarily by agricultural chambers, following the example of their Western European counterparts. Recently, there have been attempts to limit the powers of local governments and self-governing entities in Poland, to be subsequently exercised by the central government; these centralist tendencies can be considered a departure from the principles of a democratic state and the rule of law, where organized groups of citizens are granted the privilege of managing their own affairs.

At the same time, the respondents indicated (68\%) that despite the statutory ability to perform tasks in the field of government administration or local government, the chambers are not vested with such tasks. The chambers demand that they be consulted on many issues affecting the sustainable development of agriculture and rural areas. The leaders (94\%) indicated that agricultural chambers should be able to express their opinions on spatial development plans and studies of the conditions and directions of spatial development in the case of rural areas. According to the respondents (95\%), local government units should be obliged to consult agricultural chambers on decisions on land development conditions (for investments located in the immediate vicinity of agricultural land or farming plots); and in the process of issuing decisions on environmental conditions of consent for a project (also known as environmental decisions) concerning rural areas, the opinions of agricultural chambers should also be taken into account (95\%). Additionally, the self-governing agricultural bodies should have a say when deciding on the establishment, liquidation, increase or reduction of nature protection areas, such as national parks, landscape parks, nature reserves, Natura 2000 areas, protected landscape areas and their buffer zones, and so on.

One of the questions concerned the method of financing the self-governing agricultural bodies in Poland. Most of the respondents stated that the financing principles did not guarantee that the tasks imposed on agricultural chambers would be properly implemented. The method of financing agricultural chambers was assessed as inadequate, given the challenges faced by them $(68 \%)$.

The additional, supplementary statements of the respondents show that the chambers are not viewed by farmers and the rest of the society as a strong or important representative of their circles or, at the same time, as a public administration entity caring for the public interest. This is also confirmed by studies carried out by the Ministry of Agriculture and Rural Development. This is due to the poor levels of awareness of the members of agricultural chambers as to their self-governing potential, but also due to the fact that agricultural chambers mostly formulate postulates and express opinions, and do not exercise executive power. Farmers realize that agricultural chambers have limited powers, they do not have the full status of decentralized public administration entities, and they cannot interact with central administration and local governments on an equal footing. Their actual influence on state agricultural policy, the development of agriculture and rural areas, and on sustainable development is limited. 
In the opinion of the leaders of agricultural self-governance, the chambers have the potential to play a key role in the implementation of the concept of sustainable development in accordance with the principle of decentralization of power and the principle of subsidiarity, but their participation is practically unnoticeable due to imperfect formal institutions. This is also influenced by the poor activity of delegates and other members of the chambers, which is confirmed by the elections to agricultural chambers with turnouts at the level of 4 or $5 \%$ in most regions. This has an adverse impact on the formation of civil society and embarking on the paths of lasting and sustainable development. In the opinion of the respondents, changes in the law strengthening the position of agricultural chambers, increasing farmers' knowledge, and raising their awareness as to their self-governance potential, and the promotion of self-governing agricultural bodies by central and local governments could contribute to the greatest extent to increasing the turnout in elections to agricultural chambers.

Therefore, self-governing agricultural bodies should intensify their activities promoting self-governance and try to engage more of their members. The authorities of self-governing bodies have to establish relations with their members both unilaterally, informing them about decisions taken and consulting proposed solutions with them, and bilaterally, actively initiating co-decision making, cooperation and enabling members to define problems and indicate solutions on their own. Chambers should also develop promotional activities among the public by indicating good practices and the outcomes of their activities, including those in the area of sustainable development.

In the European Union, agricultural organizations, including chambers, play a signifcant role in agricultural and rural development. Yet compared to the Polish chambers, they have greater executive powers, material resources and highly qualified specialists; they operate in a professional manner, performing an important function, organizing the agricultural market, collecting and transferring business information, providing consulting, educational and professional development. They also represent the interests of their members to the government administration, local government and the EU administration. In countries such as France, Germany, and Austria self-governing agricultural bodies associate the future of agriculture with maintaining active life in rural areas and, knowing the reality of living in the country well, coordinate municipal sustainable development projects (Assemblée Nationale, 2020; Balcerek-Kosiarz, 2017, pp. 171-183; Villemaine, 2013, pp. 6-73; Walkowiak, 2012, pp. 302-305).

The analysis of how the self-governing agricultural bodies operate in Poland shows that a mere adoption of the law which defines self-governing agricultural bodies as entities of decentralized public administration does not mean that we are dealing with true self-governance. On the one hand, the legislator appreciates the role of the self-governing agricultural bodies and has established them as public-law associations, on the other, the provisions of the same law do not 
grant agricultural chambers the powers that would allow them to fully implement the tasks they are supposed to fulfil.

\section{Conclusion}

Formal and informal instruments can impact the outcomes of actions for sustainable development to the same extent. This process requires properly functioning formal components, such as legal regulations, tenets of public policies, methods of organization and management, and administrative procedures; but informal elements, such as social and political beliefs, trust and cooperation are also important. Sustainable development goals cannot be achieved through random, individual projects, but through coordinated action at different levels of the decision-making process. For an integrated approach to sustainable development, the potentials of key development stakeholders, international organizations, national governments, self-governing organizations, non-governmental organizations and individuals need to be used. Active participation of society is a necessary condition for the implementation of the concept of sustainable development; otherwise, it will remain an idealized concept discussed in the public space, but not translated into actions and measurable outcomes. It is worth remembering that ensuring partnership and social influence on the processes of exercising power is one of the important postulates of sustainable development. Provisions in this regard were included in the 2030 Agenda for Sustainable Development.

The analysis of legal acts and official government documents as well as the survey results provide considerable justification for greater inclusion of agricultural chambers in the implementation of sustainable development postulates. At the same time, it should be noted that the scope of the powers of agricultural chambers needs to be altered because, despite being formally established in the public law system, the agricultural chambers operating in Poland play a secondary role in the process of supporting agriculture, determining the directions of its development and implementing the concept of sustainable development. The authorities of agricultural chambers are mostly of the opinion that agricultural chambers are needed in Poland on the one hand, but they are also convinced that self-governing agricultural bodies play only a superficial role in the implementation of sustainable development postulates. In this context, it seems justified to continue the research so as to include all members of the agricultural chambers in Poland. Such research could provide a more thorough review of the actual role of self-governing agricultural bodies in the process of implementing sustainable development postulates, indicate good practices and identify the sources of ineffectiveness of agricultural chambers. 


\section{References}

Adamowicz, M., \& Zwolińska-Ligaj, M. (2009). Koncepcja wielofunkcyjności jako element zrównoważonego rozwoju obszarów wiejskich. Zeszyty Naukowe SGGW: Polityki Europejskie, Finanse i Marketing, 2009, 2(51), 11-38.

Arnstein, S.R. (1969). A ladder of citizen participation. Journal of the American Institute of Planners, 35(4), 216-224. https://doi. org/10.1080/01944366908977225.

Assemblée Nationale. (2020). Rapport d'information Déposé en application de l'article 145 du Règlement. Relative aux chambres d'agriculture et à leur financement. Retrieved 15.01.2021 from https://www.assemblee-nationale.fr/dyn/15/ rapports/miccaf/l15b3702_rapport-information.

Balcerek-Kosiarz, M. (2017). Rola samorządu w sferze podnoszenia konkurencyjności regionów w Polsce i Niemczech. Elipsa.

Bandarzewski, K. (2014). Samorzad gospodarczy w prawie polskim: studium prawne. Uniwersytet Jagielloński.

Bernaciak, A., Springer, A., \& Walkowiak, K. (2018). Partycypacja obywatelska w zarządzaniu miastem z perspektywy wielkopolskich burmistrzów. SpaceSociety-Economy, 24, 105-122. https://doi.org/10.18778/1733-3180.24.07.

CBOS. (2018). Komunikat z badań: zaangażowanie Polaków na rzecz spoteczności lokalnej. Retrieved 15.01.2021 from https://www.cbos.pl/SPISKOM. POL/2018/K_074_18.PDF.

Chatwin, M., Arku, G., \& Cleave, E. (2019). Defining subnational open government: does local context influence policy and practice. Policy Sciences, 52, 451-479. https://doi.org/10.1007/s11077-018-09347-7.

Collste, D., Pedercini, M., \& Cornell, S.E. (2017). Policy coherence to achieve the SDGs: using integrated simulation models to assess effective policies. Sustainability Science, 12, 921-931. https://doi.org/10.1007/ sl1625-017-0457-x.

European Commission. (2015). Communication from the Commission to the European Parliament, the Council, the European Economic and Social Committee and the Committee of the Regions: a global partnership for poverty eradication and sustainable development after 2015 (COM/2015/044).

Godłów-Legiędź, J. (2009). Instytucje i koszty transakcji jako podstawowe pojęcia nowej ekonomii instytucjonalnej. In J. Godłów-Legiędź (Ed.), Instytucje i transformacja (pp. 11-32). Adam Marszałek.

Hodgson, G.M. (2004). The evolution of institutional economics: agency, structure and darwinism in America institutionalism. Routledge. https://doi. org/10.4324/9780203300350.

Klimczak, B. (2001). Teoretyczne podstawy badania ładu rynkowego działań grup interesu na rzecz ładu rynkowego. In B. Klimczak (Ed.), Samorząd gospodarczy i zawodowy $w$ procesie powstawania tadu rynkowego $w$ Polsce (pp. 11-64). Akademia Ekonomiczna im. Oskara Langego we Wrocławiu. 
Kmieciak, R. (2018). Formy samorzadu w Polsce: wymiar terytorialny i specjalny. WNPiD UAM.

Kołodziejczyk, D. (Ed.). (2013). Instytucjonalne uwarunkowania rozwoju infrastruktury jako gtównego czynnika zrównoważonego rozwoju rolnictwa i obszarów wiejskich. Retrieved 15.10.2021 from https://depot.ceon.pl/bitstream/handle $/ 123456789 / 3838 / 85$. pdf? sequence $=1 \&$ isAllowed $=\mathrm{y}$.

Mensah, J. (2019). Sustainable development: meaning, history, principles, pillars, and implications for human action: literature review. Cogent Social Sciences, 5, 1653531. https://doi.org/10.1080/23311886.2019.1653531.

North, D.C. (1990). Institutions, institutional change and economic performance. Cambridge University Press. https://doi.org/10.1017/CBO9780511808678.

OECD. (2019). Policy coherence for sustainable development 2019: empowering people and ensuring inclusiveness and equality. https://doi.org/10.1787/a90f85lf-en.

Ostrom, E. (1990). Governing the commons: the evolution in institutions for collective action. Cambridge University Press.

Pawlewicz, K., \& Pawlewicz, A. (2010). Rola partycypacji społecznej na rzecz zrównoważonego rozwoju obszarów wiejskich. Zeszyty Naukowe SGGW w Warszawie. Ekonomika i Organizacja Gospodarki Żywnościowej, 83, 71-80.

Pawłowski, A. (2017). Rozwój zrównoważony: największe wyzwanie XXI wieku. In R.F. Sadowski, \& Z. Łepko (Eds.), Teoria i praxis zrównoważonego rozwoju: 30 lat od ogtoszenia „Raportu Brundtland” (pp. 53-64). TNFS. https://doi.org/10.21852/tnfs.2017.2.

Popławski, T. (2000). Kształtowanie świadomości ekologicznej. Ekonomia i Środowisko, 1(16), 145-151.

Pretty, J.N. (1995). Participatory learning for sustainable agriculture august. World Development, 23(8), 1247-1263. https://doi. org/10.1016/0305-750X(95)00046-F.

Przybylska, A., \& Giza, A. (2014). Partycypacja obywatelska: od teorii do praktyki spotecznej. Scholar.

Rada Ministrów. (2017). Strategia na rzecz Odpowiedzialnego Rozwoju do roku 2020 (z perspektywa do 2030 r.). Retrieved 10.11.2020 from https://www. miir.gov.pl/media/48672/SOR.pdf.

Rada Ministrów. (2018). Realizacja celów zrównoważonego rozwoju w Polsce: raport 2018. Retrieved 10.11.2020 from https://www.mpit.gov.pl/media/54729/ Raport_VNR_wer_do_uzgodnien_20180330.pdf.

Rada Ministrów. (2019). Strategia zrównoważonego rozwoju wsi rolnictwa i rybactwa 2030. Retrieved 10.11.2020 from https://www.gov.pl/web/rolnictwo/ dokumenty-analizy-szrwrir-2030.

Rudolf, W. (2015). Możliwości wykorzystania nowej ekonomii instytucjonalnej w rozwoju sektora publicznego. Zarządzanie Publiczne, 2(30), 109-118. https://doi.org/10.4467/20843968ZP.15.010.3581. 
Saner, R., Yiu, L., \& Nguyen, M. (2019). Monitoring the SDGs: digital and social technologies to ensure citizen participation, inclusiveness and transparency. Development Policy Review, 38(4), 483-500. https://doi.org/10.1111/ dpr.12433.

Springer, A., Bernaciak, A., \& Walkowiak, K.(2020). Leadership styles of rural leaders in the context of sustainable development requirements: a case study of commune mayors in the greater Poland province, Poland. Sustainability, 2(7), 2676. https://doi.org/10.3390/sul2072676.

Szostok-Nowacka, P.E. (2019). Znaczenie poczucia podmiotowości dla aktywności społecznej w przestrzeni Samorządowej. Annales Universitatis Mariae Curie-Sktodowska, Sectio K: Politologia, 26(1), 141-157. https://doi.org/10.179 51/k.2019.26.1.141-157.

Tosun, J., \& Leininger, J. (2017). Governing the interlinkages between the sustainable development goals: approaches to attain policy integration. Global Challenges, 1(9), 1700036. https://doi.org/10.1002/gch2.201700036.

United Nations. (1992). Agenda 21. Retrieved 30.08.2021 from https://sustainabledevelopment.un.org/content/documents/Agenda21.pdf.

United Nations. (2015). Transforming our world: the 2030 agenda for sustainable development. Retrieved 30.08.2021 from https://www.un.org/ga/search/ view_doc.asp? symbol=A/RES/70/1\&Lang=E.

Villemaine, R. (2013). Le conseil agricole des chambres d'agriculture et des coopératives: entre convergence et différenciation. Pour, 219, 67-73. https://doi.org/10.3917/pour.219.0067.

Walkowiak, K. (2004). Rola izb rolniczych w rozwoju wsi i rolnictwa w Polsce. Wyższa Szkoła Bankowa w Poznaniu.

Walkowiak, K. (2012). Izby rolnicze w świadomości rolników Wielkopolski. In S. Wykrętowicz (Ed.), Samorząd w Polsce: istota, formy, zadania (pp. 295306). Wyższa Szkoła Bankowa w Poznaniu.

WCED. (1987). Report of the World Commission on Environment and Development. Retrieved 20.10.2020 from https://digitallibrary.un.org/ record $/ 133790$ ? $\ln =$ en.

Wykrętowicz, S. (2012). Samorząd jako wyraz demokracji obywatelskiej. In S. Wykrętowicz (Ed.), Samorząd w Polsce: istota, formy, zadania (pp. 13-92). Wyższa Szkoła Bankowa w Poznaniu.

Zielińska, E., \& Kraszewski, D. (2019). Narzędzia partycypacji lokalnej w Polsce w latach 2014-2017. Retrieved 10.11.2020 from https://partycypacjaobywatelska.pl/wp-content/uploads/2019/03/narzedzia-partycypacji-lokalnej-wpolsce-w-latach-2014-2017.pdf.

Zieliński, E.L. (2012). Rola izb przemysłowo-handlowych w kształtowaniu środowiska przedsiębiorców. In S. Wykrętowicz (ed.), Samorząd w Polsce: istota, formy, zadania (pp. 307-320). Wyższa Szkoła Bankowa w Poznaniu. 


\section{Acknowledgements}

Author contributions: author has given an approval to the final version of the article.

Funding: this research was fully funded by the author's own sources.

Note: the results of this study were presented at 4th Scientific Conference: Institutions in Theory and Practice (March 25-26, 2021, Wrocław, Poland). 
